\title{
PENGARUH PENAMBAHAN TAPAI SINGKONG TERHADAP SIFAT ORGANOLEPTIK SAMBAL TEMPOYAK
}

\section{EFFECT OF CASSAVA TAPAI ADDITION ON ORGANOLEPTIC PROPERTIES OF "TEMPOYAK"}

\author{
Mukmin ${ }^{1}$, Lina Widawati ${ }^{2}$, Siska Apriyani $^{3}$ \\ 1) Program Studi Teknologi Pangan Fakultas Pertanian UNIVED \\ 2) Program Studi Teknologi Pangan Fakultas Pertanian UNIVED \\ 3) Program Studi Teknologi Pangan Fakultas Pertanian UNIVED
}

\begin{abstract}
ABSTRAK
Tempoyak merupakan makanan hasil olahan buah durian yang di peroleh dengan cara fermentasi sederhana, bentuknya berupa bubur daging durian dengan rasa asam. Tempoyak dibuat dengan penambahan garam sebanyak 1-5\% kedalam daging buah buah yang kemudian diperam selama 3-4 hari. Penelitian ini bertujuan untuk mengetahui tingkat kesukaan konsumen terhadap sambal tempoyak dengan penambahan tapai singkong. Metode penelitian yang digunakan dalam pembuatan sambal tempoyak dengan penambahan tapai singkong, yaitu dengan cara mengolah tempoyak dengan tapai singkong menjadi sambal tempoyak, dengan perlakuan komposisi tapai singkong(tempoyak $500 \mathrm{gr}$ : 0 gr tapai singkong, tempoyak $450 \mathrm{gr}$ : $50 \mathrm{gr}$ tapai singkong dan tempoyak 400 gr : 100 gr tapai singkong). Dengan menggunakan analisis uji organoleptik denga parameter warna, rasa, dan aroma sambal tempoyak yang diujikan terhadap 20 panelis. Hasil analisis yang dilakukan menyatakan bahwa berdasarkan parameter warna, menunjukkan perbedaan yang nyata antara ketiga sampel. Dimana panelis lebih memilih sambal tempoyak dengan penambahan 0 gram dan 50 gram singkong tapai. Berdasarkan parameter rasa, tidak menunjukkan perbedaan yang nyata antara ketiga sampel. Berdasarkan parameter aroma, menunjukkan perbedaan yang nyata antara ketiga sampel. Dimana panelis lebih memilih sambal tempoyak dengan penambahan 50 gram dan 100 gram singkong tapai .
\end{abstract}

Kata kunci : Tempoyak, tapai singkong, cabai tempoyak

\begin{abstract}
Tempoyak is a durian processed foods obtained by simple fermentation, the shape of the pulp of durian flesh with a sour taste. Tempoyak made with the addition of as much as 1-5 $\%$ salt into the flesh of the fruit pieces which are then brooded for 3-4 days. This study aims to determine the level of consumer preference towards tempoyak sauce with the addition of cassava tapai. The method used in making sauce with the addition of cassava tapai tempoyak, namely by processing cassava into tempoyak with tapai tempoyak sauce. The treatment in this study is the composition variation tapai cassava ( tempoyak 500 grams : 0 grams tapai cassava, tempoyak 450 grams : 50 grams of cassava and tempoyak tapai 400 grams : 100 grams tapai cassava). The analysis used was the analysis of organoleptic parameters premises color, flavor, and aroma of chili tempoyak tested against the 20 panelists. The results of the analysis conducted stated that based on the parameters of color, showing significant difference between the three samples. Where consumers prefer chili tempoyak with the addition of 0 grams and 50 grams of cassava tapai. Based on the parameters of taste, showed no significant difference among the three
\end{abstract}


samples. Based on the parameters of aroma, showing significant difference between the three samples. Where consumers prefer chili tempoyak with the addition of 50 grams and 100 grams of cassava tapai.

Keywords : Tempoyak, tapai cassava, chilli tempoyak

\section{PENDAHULUAN}

Buah durian adalah buah dengan kulit tebal dan beraroma menyengat merupakan salah satu jenis buah yang banyak diminati oleh banyak orang di Indonesia. Bukan karena banyak dijumpai dipasar-pasar tradisional ataupun di super market, melainkan buah durian memang mempunyai peminat tersendiri yang jumlahnya cukup banyak dibandingkan peminat buah lainnya.

Tanaman buah durian merupakan tumbuhan kelas dicotyledonae atau biji keeping dua dan termasuk jenis durio. Buah ini juga termasuk buah musiman yang berproduksi pada masa tertentu saja, jika waktu musim tiba maka dapat dibeli dengan harga cukup murah. Buah durian selain dapat dikonsumsi dalam keadan segar dapat juga diolah menjadi berbagai bentuk olahan seperti tempoyak,dodol durian,lempuk yang biasanya dimakan sebagai makanan yang dihidangkan pada saat pesta atau hari raya (Anonim,1990).

Untuk memperpanjang umur simpan buah durian, maka dilakukan pengolahan menjadi berbagai macam produk, salah satunya tempoyak. Menurut Antarlina
(2010), tempoyak merupakan makanan hasil olahan buah durian yang diperoleh dengan cara fermentasi sederhana, bentuknya berupa bubur daging buah durian dengan rasa asam. Tempoyak dibuat dengan penambahan garam sebanyak $1-1,5 \%$ ke dalam daging buah yang kemudian diperam selama 3-4 hari. Selain itu, penambahan inokulum juga terbukti membuat waktu fermentasi tempoyak lebih singkat, yaitu 2-3 hari (Veronika, 2005: Yuliana dkk, 2005) dari umumya 7-10 hari.

Rasa asam pada tempoyak berkait dengan aktivitas bakteri asam laktat seperti Lactobasillus Plantarum, Lactobasillus Brevis, Lactobasillus Mali, Lactobasillus Fermentum, Lactobasillus Casei, Lactobasillus Corynebacterium, dan Lactobasillus Durianis Sp (Yuliana, 2004). Bakteri asam laktat mempunyai peran esensial hampir dalam semua proses fermentasi makanan dan minuman. Peran utama bakteri ini dalam industri makanan adalah untuk pengasaman bahan mentah dengan memproduksi sebagian besar asam laktat, asam asetat, etanol, dan $\mathrm{CO}_{2}$ (Desmazeaud, 1996). Bakteri asam laktat 
banyak digunakan dalam produk susu seperti yogurt, sour crem (susu asam), keju, mentega dan produksi asamasaman, seperti asinan (Lindiquist,1998).

Menurut Rahayu dkk (1995) pada fermentasi tempoyak diperlukan bakteri asam laktat yang diduga adalah Lactobasillus Casei sub Sp Rhamnosus yang bersifat fluktuatif heterofermatif dan Lactobasillus Fersantum yang bersifat heterofermentatif. Tempoyak yang rasannya asam ini bisa menjadi bahan makanan seperti sambal tempoyak, saus tempoyak atau untuk campuran memasak ikan. Tempoyak dikenal di Indonesia terutama di daerah Kalimantan dan Sumatera, termasuk di daerah Bengkulu.

Tempoyak diolah dengan cara fermentasi, fermentasi merupakan proses penguraian gula menjadi alkohol dan $\mathrm{CO}_{2}$ yang berlangsung karena adanya ekstrak khamir atau sebenarnya enzimenzim yang terdapat dalam ekstrak tersebut. Fermentasi daging buah durian menjadi tempoyak dapat dilakukan secara spontan. Umumnya pembuatan tempoyak di masyarakat dilakukan secara tradisional dan sifatnya spontan tanpa penambahan inokulum atau kultur murni. Produksi maksimum dalam fermentasi dipengaruhi faktor-faktor inkubasi, $\mathrm{pH}$ medium, oksigen, cahaya dan agitasi. Dari penjelasan di atas maka perlu adanya penelitian terhadap pengaruh lama waktu fermentasi tempoyak terhadap sifat organoleptik saus tempoyak.

\section{METODE PENELITIAN}

\section{Bahan dan Alat}

Bahan-bahan yang akan digunakan dalam penelitian pengolahan tempoyak adalah buah durian tanpa biji, bawang merah, bawang putih, sukrosa, garam dan benzoate. Buah durian dapat diperoleh dari pedagang di Pasar Panorama Bengkulu. Bahan lain yang dugunakan untuk uji sensoris yaitu air minum sebagai penetralisir rasa. Alatalat yang akan digunakan dalam pengolahan tempoyak yaitu, pisau sendok, baskom, toples, timbangan, wajan, kompor, botol dan piring kecil.

\section{Metode}

Penelitian ini dilakukan dengan perlakuan tiga tahap yaitu pembuatan tempoyak dengan waktu fermentasi 5 hari dan kadar garam 1\%, pembuatan sambal tempoyak dengan variasi komposisi tempoyak : tapai singkong yaitu 500 gram : 0 gram, 450 gram : 50 gram dan 400 gram : 100 gram serta tahap analisis uji sensoris. 


\section{HASIL DAN PEMBAHASAN}

Sifat Organoleptik Sambal Tempoyak dengan Penambahan Tapai Singkong.

Uji organoleptik merupakan salah satu cara penilaian terhadap suatu produk makanan yang dilakukan oleh manusia sebagai pengukuran dengan menggunakan panca inderanya. Indera yang berperan dalam uji organoleptik ini adalah pengecap (rasa), penglihatan (warna), penciuman, (aroma). pada penelitian ini sifat organoleptik yang diujikan kepada 20 orang panelis tetap adalah rasa, warna, dan aroma. Secara umum pengujian sambal tempoyak dengan variasi komposisi tempoyak : tapai singkong yaitu 500 gram : 0 gram, 450 gram : 50 gram dan 400 gram : 100 gram mendapatkan penilaian yang berbeda dari panelis baik dari segi rasa, warna, dan aroma dari sambal tempoyak tersebut. Hal ini menunjukkan bahwa dengan penambahan tapai singkong pada tempoyak berpengaruh terhadap rasa, warna ,dan aroma pada sambal tempoyak. Analisa uji organoleptik sambal tempoyak dengan penambahan tapai singkong dapat dilihat pada Tabel 1 dan Gambar 1.

Tabel 1. Hasil Rerata Uji Organoleptik Sambal Tempoyak

\begin{tabular}{cccc}
\hline Perbandingan & \multicolumn{3}{c}{ Penilaian } \\
\cline { 2 - 4 } Tempoyak : Tapai Singkong & Warna & Rasa & Aroma \\
\hline 500 gr : 0 gram & 2.15 & 2.5 & 2.75 \\
450 gr : 50 gram & 2.05 & 2.1 & 2.15 \\
400 gr : 100 gram & 2.7 & 2.6 & 2.45 \\
\hline
\end{tabular}

Ket : Atribut mutu=1 (sangat suka), 2(suka), 3(agak suka), 4(tidak suka), 5(sangat tidak suka) .

Sifat Organoleptik Warna Sambal

Tempoyak dengan Penambahan Tapai

\section{Singkong.}

Warna merupakan parameter organoleptik yang penting dalam suatu produk makanan. Warna merupakan parameter pertama yang menentukan tingkat penerimaan konsumen terhadap warna sambal tempoyak akibat penambahan tapai singkong 0 gram, 50gram, 100gram berkisar antara 2.05 (suka) hingga 2.7 (agak suka). Hasil analisa warna sambal tempoyak dapat dilihat pada Tabel 2 dan Gambar 2. 


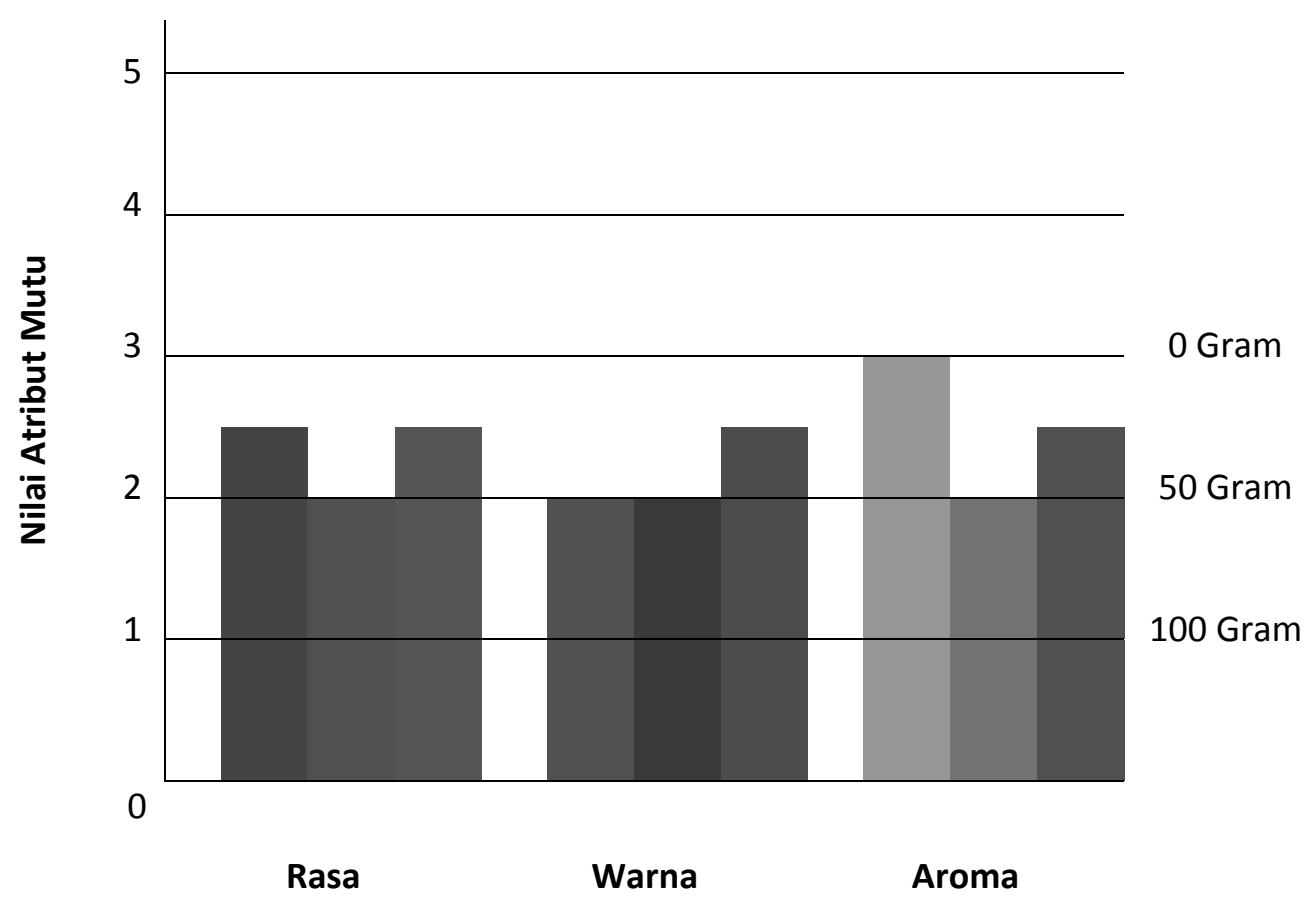

Ket : Atribut mutu = 1 (sangat suka), 2(suka), 3(agak suka), 4(tidak suka), 5(sangat tidak suka)

Gambar 1. Grafik Rerata uji organoleptik oleh panelis

Tabel 2 Hasil Rerata Uji Kesukaan Warna Sambal Tempoyak dengan Penambahan Tapai Singkong.

\begin{tabular}{cc}
\hline Perbandingan & Penilaian \\
Tempoyak : Tapai Singkong & Warna \\
\hline 500 gram : 0 gram & 2.15 \\
450 gram : 50 gram & 2.05 \\
400 gram : 100 gram & 2.70 \\
\hline
\end{tabular}

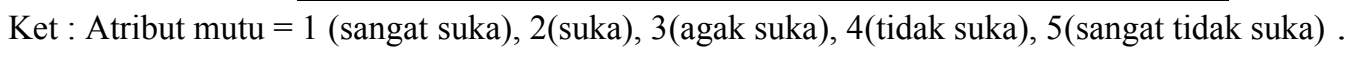

Tabel 3. Anova Berdasarkan Warna.

\begin{tabular}{lrrrcc}
\hline Sumber Keragaman & dB & JK & KT & Fhit & Ftabel \\
\hline Panelis & 19 & 10.6 & 0.55 & 1.22 & 1.86 \\
Perlakuan & 2 & 4.9 & 2.45 & 5.44 & 3.25 \\
Galat & 38 & 17.1 & 0.45 & & \\
Total & 59 & 32.6 & & & \\
F Hitung > F tabel : berbeda nyata & & & \\
F Hitung < F tabel : tidak berbeda nyata.
\end{tabular}

Berdasarkan Tabel 2 dan Tabel 3 hasil penelitian uji kesukaan terhadap warna saus tempoyak memiliki perbedaan antara ketiga sampel. Diketahui bahwa penilaian rerata oleh 20 panelis pada penambahan 0 gram tapai singkong yaitu 
2.15 (suka) ,sedangkan pada penambahan tapai singkong 50 gram yaitu 2.05 (suka) dan pada penambahan 100 gram tapai singkong yaitu 2.70 (agak suka).

Pada penilaian warna sambal tempoyak panelis lebih menyukai penambahan tapai singkong 0 gram, dan 50 gram .Pada sambal tempoyak dengan penambahan 0 gram tapai singkong menumbulkan warna merah yang cerah, Penambahan 50 gram tapai singkong menimbulkan warna merah, sedangkan pada penambahan 100 gram tapai singkong dari sambal tempoyak merah yang lebih gelap. Karena komponen yang ada dalam tapai singkong dapat membuat perubahan warna pada kedua perlakuan yakni 450 gram tempoyak : 50gram tapai singkong dan 400 gram tempoyak : 100 gram tapai singkong.

\section{Sifat Organoleptik Rasa Sambal}

Tempoyak dengan Penambahan Tapai

\section{Singkong.}

Cita rasa merupakan suatu kesan yang diterima melalui saraf indera pengecapan ,yaitu lidah. Sebagai hasilhadirnya senyawa-senyawa yang larut dalam air. Secara umum ada lima cita rasa juga digunakan untuk menerangkan mutu dari kesan yang ditimbulkan oleh senyawasenyawa yang ada didalam bahan makanan atau minuman (Anonim, 2007 ). Rerata kesukaan konsumen terhadap rasa sambal tempoyak akibat penmbahan 0 gram, 50 gram, 100 gram tapai singkong berkisar antara 2.10 (suka) sampai 2.25 (suka). Hasil pada tabel 4 berikut :

Tabel 4. Hasil Rerata Uji Kesukaan Rasa Sambal Tempoyak dengan Penambahan Tapai Singkong

\begin{tabular}{cc}
\hline Perbandingan & Penilaian \\
Tempoyak : Tapai Singkong & Rasa \\
\hline 500 gram : 0 gram & 2.50 \\
450 gram : 50 gram & 2.10 \\
400 gram : 100 gram & 2.60 \\
\hline but mutu = 1(sangat suka), 2(suka), 3(agak suka), 4(tidak suka),5 (sangat tidak suka)
\end{tabular}

Tabel. 5 . Anova Berdasarkan Rasa.

\begin{tabular}{cccccc}
\hline Sumber Keragaman & dB & JK & KT & Fhit & Ftabel \\
\hline Panelis & 19 & 11.73 & 0.617544 & 0.44 & 1.86 \\
Perlakuan & 2 & 2.8 & 1.4 & 2.97 & 3.25 \\
Galat & 38 & 17.86 & 0.470175 & & \\
Total & 39 & 32.4 & & & \\
\hline
\end{tabular}

F Hitung $>$ F tabel : berbeda nyata.

F Hitung $<$ F tabel : tidak berbeda nyata. 
Berdasarkan gambar 5 diketahui bahwa penilaian uji kesukaan terhadap rasa sambal tempoyak dengan penambahan tapai singkong tidak memiliki perbedaan yang nyata antara ketiga sampel. Diketahui bahwa rerata dari penilaian tingkat kesukaan dari 20 panelis terhadap rasa sambal tempoyak dengan penambahan tapai singkong menunjukan rerata 2.10 (suka) hingga 2.60 (agak suka). Pada penambahan 0 gram tapai singkong dengan penilaian 2.50 (agak suka) sedangkan pada penambahan 50 gram tapai singkong berkisar 2.10 (suka) dan penambahan 100 gram tapai singkong berkisar 2.60 (agak suka).

Rasa sambal tempoyak dengan penambahan 50 gram tapai singkong menimbulkan rasa yang tidak terlalu asam, sedangkan pada penambahan 0 gram tapai singkong rasa yang ditimbulkan sedikit asam dengan rasa manis dari daging buah durian masih terasa. Sedangkan pada penambahan 100 gram tapai singkong menimbulkan rasa yang asam karena komponen yang ada dalam tapai singkong dapat membuat perubahan rasa pada perlakuan 450 gram tempoyak : 50 gram tapai singkong.

Sifat Organoleptik Aroma Sambal Tempoyak Dengan Penambahan Tapai Singkong •

Aroma berhubungan dengan komponen volatile dari suatu bahan. Semakin banyak komponen volatil yang terdapat pada suatu bahan maka aroma yang terbentuk akan lebih tajam. Selain itu aroma dapat digunakan sebagai indikator kelayakan suatu produk pangan, dapat diterima atau tidaknya suatu produk pangan oleh konsumen. Rerata penilaian aroma sambal tempoyak dengan penambahan 0 gram, 50 gram, dan 100 gram tapai singkong oleh panelis berkisar antara 2,15 (suka) hingga 2,75 (agak suka). Hasil analisis aroma sambal tempoyak Dengan penambahan tapai singkong dapat dlihat pada Tabel 6 dan Tabel 7.

Tabel 6. Hasil Rerata Uji Kesukaan Aroma Sambal Tempoyak dengan Penambahan Tapai Singkong

\begin{tabular}{lc}
\hline \multicolumn{1}{c}{ Perbandingan } & Penilaian \\
Tempoyak : Tapai Singkong & Aroma \\
\hline 500 gram : 0 gram & 2.75 \\
450 gram : 50 gram & 2.15 \\
400 gram : 100 gram & 2.45
\end{tabular}

Ket : Atribut mutu=1(sangat suka), 2 (suka), 3 (agak suka), 4(tidak suka), 5( sangat tidak suka) 
Tabel 7. Anova Berdasarkan Aroma

\begin{tabular}{cccccc}
\hline Sumber Keragaman & dB & JK & KT & F hit & F tabel \\
\hline Panelis & 19 & 8.85 & 0.46 & 1.44 & 1.86 \\
Perlakuan & 2 & 3.6 & 1.5 & 4.69 & 3.25 \\
Galat & 38 & 12.4 & 0.32 & & \\
Total & 39 & 24.85 & & & \\
\hline
\end{tabular}

F Hitung $>\mathrm{F}$ tabel : berbeda nyata.

F Hitung $<$ F tabel : tidak berbeda nyata.

Berdasarkan Tabel 6 dan Tabel 7 hasil penilaian aroma sambal tempoyak dengan penambahan tapai singkong menunjukkan perbedaan antara ketiga sampel. Diketahui bahwa rerata penilaian tingkat kesukaan konsumen dari panelis menunjukkan penilaian 2,75 (agak suka) pada penambahan 0 gram tapai singkong sedangkan pada penambahan 50 gram tapai singkong mendapatkan penilaian 2,15 (suka) dan pada penambahan 100 gram tapai singkong penilaian 2,45 (suka).

Pada penilaian aroma sambal tempoyak oleh 20 panelis lebih menyukai aroma sambal tempoyak dengan penambahan 50 gram dan 100 gram tapai singkong dibandingkan dengan aroma pada sambal tempoyak dengan penambahan 0 gram tapai singkong. Dimana sambal tempoyak dengan penambahan 50 gram dan 100 gram tapai singkong masih menimbulkan aroma khas tempoyak yaitu aroma sedikit asam dan alkohol dari tapai singkong, Sedangkan pada penambahan 0 gram tapai singkong aroma yang ditimbulkan masih aroma dari daging buah durian.

Tapai atau tape singkong (ubi kayu) merupakan hasil fermentasi dari ubi kayu. Singkong (ubi kayu) adalah termasuk jenis umbi-umbian yang banyak terdapat di seluruh daerah di Indonesia. Proses fermentasi yang dilakukan terhadap singkong (ubi kayu) ini menghasilkan gula dan alkohol, sehingga tapai menjadi berasa manis, sedikit asam dan beraroma alcohol (Karina, 2012).

\section{SIMPULAN}

Berdasarkan parameter warna, menunjukkan beda nyata antara ketiga sampel, dimana konsumen lebih menyukai sambal tempoyak dengan penambahan 0 gram dan 50 gram tapai singkong dengan penilaian 2,15(suka) dan 2,05 (suka). Berdasarkan parameter rasa, menunjukkan tidak beda nyata antar ketiga sampel dimana konsumen menyukai sambal tempoyak dengan penambahan 0 gram, 50 gram dan 100 gram tapai singkong dengan penilaian 
2,1 (suka), 2,5 (agak suka) dan 2,6 (agak suka). Berdasarkan parameter aroma, menunjukkan beda nyata antara ketiga sampel dimana konsumen lebih menyukai sambal tempoyak dengan penambahan 50 gram dan 100 gram tapai singkong dengan penilaian 2.15 (suka) dan 2,45 (suka).

\section{DAFTAR PUSTAKA}

Anonim, 1990, Budidaya Durian,BIP,Bengkulu.

Antarlina, SS, N. Izzudin dan U. Sudirman. 2010. Karakteristik Fisik dan Kimia Buah Eksotik Lahan Rawa serta Potensi Pemanfaatannya sebagai Pangan.http://balittra.litbang.dept an.go.id/eksotik/Monograf\%20208.pdf

Desmazeuad, M., 1996, Lactic Acid Bacteria in Food: Use and Safety, Cahiers Mada, Jogjakarta.

Lindqust, J., 1998. General Overview of

The Lactid Acid Bacteria, Departement of Bacteriology, University of Wisconsin, Madison.

Rahayu, ES., Sudarmadji, D Wibowo, dan TF. Djaafar. 1995. Isolasi Bakteri Asam Laktat dan Karakteristik Agensia yang Berpotensi Sebagai Biosafety Makanan Indonesia. Laporan Penelitian PAU Pangan dan Gizi. UGM, Yogyakarta.

Veronika, F, 2005, Karakter Tempoyak yang Diinokoladi dengan $P$. Actdilactici, Skripsi Fakultas Pertanian, Universitas Lampung, Bandar Lampung.

Yuliana, N., dkk, 2005, Produksi

Tempoyak secara Terkontrol Menggunakan Pedlococcus Acidilaticl Sebagai Tester.
Laporan Penelitian RG-TPSDP

Batch 1, Universitas Lampung, Bandar Lampung. 